\title{
A TANÁRI KOMPETENCIA RENDSZERE A NÉMET NYELVTERÜLET IRODALMA ALAPJÁN
}

\section{LÜKÖ ISTVÁN}

a Nyugat-magyarországi Egyetem Szakmai Tanárképző Intézetének

egyetemi docense

luko.istvan@bpk.nyme.hu

\begin{abstract}
Ez az írás „A szakmai tanárképzés helyzete és korszerüsitése c. FKA-KT 4/2006” c. kutatás keretében elkészült beszámoló elöadás és tanulmány alapján készült. A szakmai tanárképzés kompetenciaalapú és modulrendszerü fejlesztése, a gyakorlati felhasználás szempontjából mérvadó középfokú szakképzés fejlesztésével szervesen kell, hogy kapcsolódjon. Célunk az volt, hogy az angolszász nyelvterület kompetencia rendszere mellett, megismertessük a német nyelvterület koncepcióit, modelljeit a szakmai tanárképzés egészébe beágyazottan. A konkrét német és osztrák modellek ismertetése elött néhány gondolat megvilágítja a modul és a kompetencia fogalmi rendszerét és elemeinek kapcsolódását, mintegy érzékeltetve azt, hogy a tananyagok, igy a szakképzés és a tanárképzés tartalmi körei is, több évtizedes szerves fejlödés és fejlesztés folyamatában alakultak ki.
\end{abstract}

\section{Bevezetés}

A hazai tanárképzés átalakulása jelentős filozófiai-szemléleti, szerkezeti, módszertani váltáson megy keresztül. Leginkább a tanári kompetenciák és azok fejlesztése, a gyakorlati oktatás, a rezidens jellegü egybefüggő nevelési-oktatási gyakorlat szakmai-szervezési és módszertani kérdései kerülnek előtérbe. Erről szólt a Tanárképzők Szövetsége legutóbbi győri rendezvénye, amely az érintettek közötti komoly szakmai konszenzuson is alapuló operatív, interaktív munkája révén nagymértékben hozzájárult az elörelépéshez.

Ebben a tanulmányban a továbbhaladáshoz, a konkrét fejlesztésekhez is szükséges fogalmak (kompetencia, modul stb.) német nyelvterületi elemzésére, valamint tanárképzési modellek elemző bemutatására vállalkoztam azzal a céllal, hogy a külföldi példák kitekintései kellő nyomatékkal szolgáljanak a bizonytalannak tűnő részletek kimunkálásában. Leginkább a szakmai tanárképzési modellek kerülnek elö, amelyek bemutatására más hazai forrásban kevésbé került sor (Tóth, 2006), ugyanakkor a tanárképzés egészére nézve is kellő inspirációt, megszívlelhető aspektust szolgálnak. Mivel a kompetencia is és a modularizáció is szorosan kötődik a szakképzéshez, illetve annak modelljeihez, értelemszerúen az ezekkel foglalkozó irodalmak, és fejlesztési programok elemzése volt az egyik nagy téma ezen a területen belül. 
A német nyelvterületen folyamatosan nyomon követték, illetve fejlesztették a tananyag modularizációt, annak fontosabb állomásait. Ez a munkaerő-piaci változások követésén alapuló rendszer lényegében négy fontosabb korszakon át jutott el 1970 óta napjaink tréning modelljéhez, a Modular Traning Package (MTP) modellig. Mivel ebben zömében a német egyetemek és szakképzésfejlesztéssel, -kutatással foglalkozó szakemberek vettek részt, ezért az International Labor Office (ILO) kezdettől fogva beépítette a nemzetközi modelljeibe, illetve koncepcióiba. A Modul of Employable Skill (MES) - Modul of Employable Qualifikation (MEQ) - Modul of Employable Competence MEC-n át folyamatosan követhető a koncepciók változása. Ezeket az InWent németországi Szakképzésfejlesztési Központ számos európai és kontinensen kívüli országban projektek formájában kipróbálta, elsősorban a tanárok továbbképzésében. Többek között ezekkel a projektekkel, programokkal foglalkozó írásokban találhatunk utalást a témánk szempontjából fontos fogalmakról (modul, kompetencia, modularizáció stb.). A német egyetemek, illetve föiskolák nem egységesen vezetik be a BSc és MSc rendszerü oktatást, eddig is eltérőek voltak a tanárképzési modelljeik. Az alábbiakban néhány mérnöktanár képzési hely modelljeiből mutatunk be részleteket példaként. Ausztriában követik nagyjából a német tanárképzési modelleket, de van ahol fáziskésés van. Sajátos német nyelvterületi modell az ING.PEAD IGIP, vagyis az IGIP Mérnökpedagógusi modell. Ebben van legjobban kidolgozva a mérnöktanári szak kompetencia rendszere. Munkánk gerincét ennek a bemutatása teszi ki. Ebből nem csak a pedagógus kompetenciákat, hanem a tantervet is megismerhetjük a maga teljességében, ami hasznos lehet a magyarországi MSc mérnöktanár szakok kialakítása szempontjából is.

\section{A kompetencia fogalma és jelentése általában. Összefüggés a Képesség-Kvalifikáció-Kompetencia között}

Amint azt már más helyen is jeleztük, a képességekről a kompetenciára fókuszálódott a figyelem, ezért először az értelmezését tekintjük át az általános, majd az oktatási vonatkozásokban. Az általános értelmezés szerint a kompetencia illetékességet, alkalmasságot jelent. Az oktatási vonatkozásban egy hármas léptékü modellben ábrázolhatjuk az összefüggéseket. Az oktatásban /képzésben az átfogó munkaterület jelenti az illetékességet, amelyen belül az egyes feladatok elvégzéséhez jogosultság tartozik. Mivel a munka és a tanulás ebben a felfogásban is szorosan kapcsolódik, ezért a feladat, a tevékenység megtanulásához és az elvégzéséhez, képességeket kell fejleszteni. Így e hármas fogalmi tagolódás a következő lesz:

- Munka/szakterület kiterjedtsége (kompetencia térkép)

- Tevékenységek, szakmai feladatok köre

- A munkához/ tanuláshoz szükséges képességek, készségek, maga a tudás, mint magasabb tanulási teljesítmény

- Kulcskvalifikációk/képességek 
A kompetencia azonban összetettebb fogalom, mert a személyiség viszonyulása (attitüdje) mellett szerepe van a környezetnek, amelyben a tudás segítségével megvalósul a tevékenység. Ezért olyan modellel ábrázolhatjuk, melynek lényege: attitüd + tudás + képességek integrálása az alkalmazásban (Szervezetfejlesztők Magyarországi Társasága, 1999).

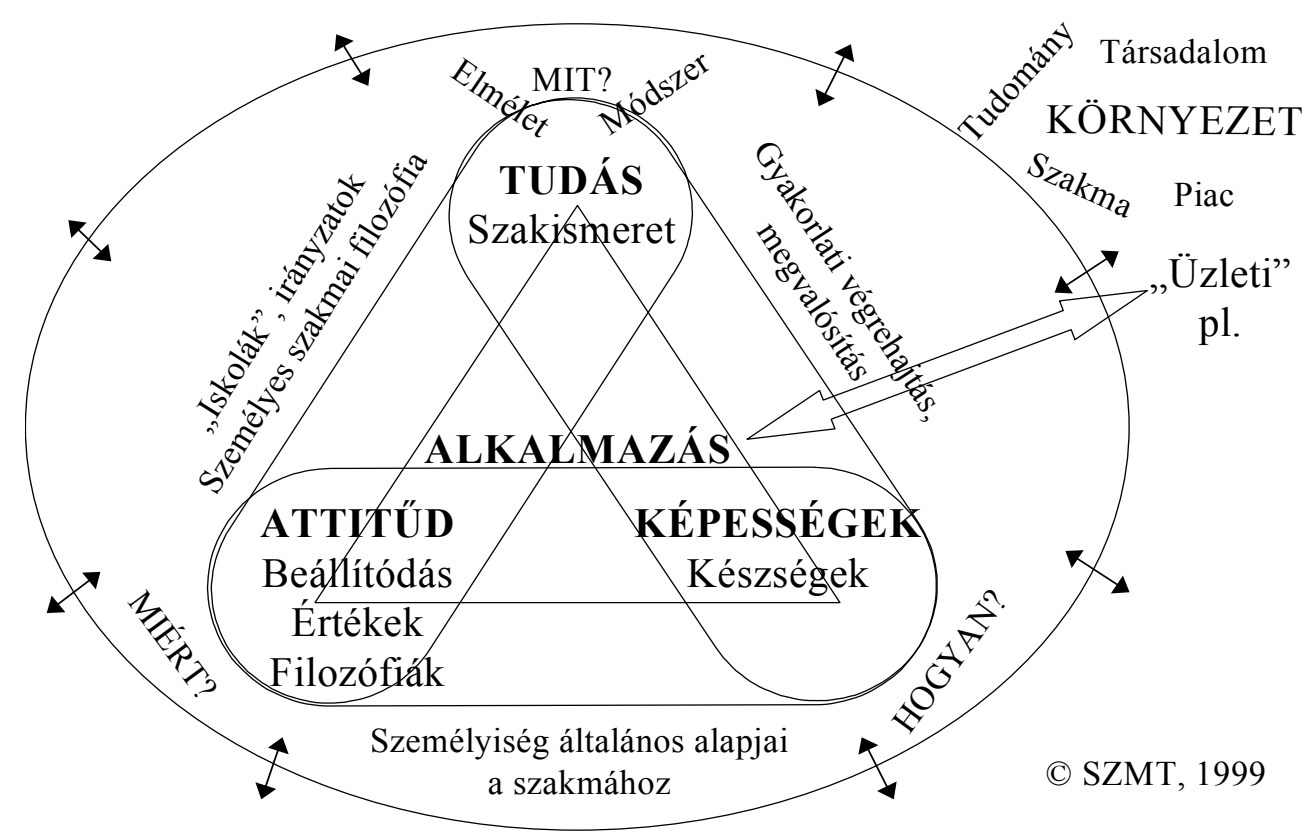

1. ábra: A szakmai kompetencia fogalmi modellje

A moduláris szemlélet szaknyelve három irányadó kifejezést használ a Vocational and Education Training (VET) folyamatok különbözö céljainak és szintjeinek a jellemzésére. Ezeket a fogalmakat és összefüggéseiket az 1. táblázatban írjuk le általánosan és konkrét példákkal.

A modellben a didaktikai és a munkaerő piaci aspektus szoros kapcsolata domborodik ki. Mindez jól példázza a német gondolkodási filozófiát, vagyis az összefüggések és a kapcsolatok komplex kezelését, tehát nem izolálódnak el az egyes kompetenciák. 
1. táblázat: A moduláris képzés központi fogalmai (Spreth és Stollte, 2003)

\begin{tabular}{|c|c|c|}
\hline Fogalom & Általános leírás & Példák \\
\hline Szakértelem & $\begin{array}{l}\text { specifikus képesség egy feladat } \\
\text { elvégzésére a pszichomotorikus } \\
\text { aspektusokra fókuszálva }\end{array}$ & $\begin{array}{l}\text { fémlemez vágása lemezollóval } \\
\text { elektromos kábelek elrendezésének } \\
\text { kijelölése vízszintezővel }\end{array}$ \\
\hline Képesség & $\begin{array}{l}\text { képesség egy feladat elvégzésére } \\
\text { tudás, specifikus szakértelem és } \\
\text { magatartás integrált használatával }\end{array}$ & $\begin{array}{l}\text { csavarmenet metszése (tudás: } \\
\text { pl. ismeri a különböző külső és } \\
\text { belső meneteket; szakértelem: } \\
\text { menetmetszés esztergán, } \\
\text { csavarmenetfúróval, vagy } \\
\text { mentvágóval; magatartás: } \\
\text { metszőszerszámok precíz és } \\
\text { biztonságos használatának akarása) }\end{array}$ \\
\hline Kompetencia & $\begin{array}{l}\text { magasabb szintű képesség és } \\
\text { diszpozíció összetett feladatok } \\
\text { elvégzésére, amely önszervező } \\
\text { alkalmazást és a megszerzett } \\
\text { képzettség új helyzetekben való } \\
\text { továbbfejlesztését követeli meg; } \\
\text { a kompetenciával kapcsolatos } \\
\text { munka magában foglalja } \\
\text { a következőket: } \\
\text { - } \quad \text { kompetencia a tárgy } \\
\quad \text { vonatkozásában, } \\
\text { - } \quad \text { módszertani kompetencia, } \\
\text { - } \quad \text { szociális kompetencia, } \\
\text { - } \quad \text { személyes kompetencia } \\
\text { A kompetenciák nem figyelhetők } \\
\text { meg közvetlenül, csak az elvégzett } \\
\text { cselekményből lehet rájuk } \\
\text { következtetni. }\end{array}$ & $\begin{array}{l}\text { egy napelemes rendszer } \\
\text { kialakításának megtervezése és } \\
\text { megvitatása a vásárlóval. } \\
\text { Az ő igényei szerint, és egy profi } \\
\text { árajánlat megtárgyalása (használja: } \\
\text { múszaki tudás, problémamegoldó } \\
\text { módszerek, tárgyalás kommunikatív } \\
\text { módon, megoldás magabiztos } \\
\text { bemutatása) }\end{array}$ \\
\hline
\end{tabular}

\section{Kompetenciák fajtái}

A kompetenciákat tovább vizsgálva a fajtáikról, típusaikról kell említést tenni. Itt is az a helyzet, hogy a nemzetközi szakirodalomban nagyon sokféle felosztás, „lista” létezik, amely szakmánként, szakterületenként nagyon eltérő szempontok alapján differenciál. Témánk szempontjából a szakképzésben leggyakrabban előforduló fajtákat soroljuk fel részletesebb ismertetés nélkül (Stollte, 2000). Ezek a következők: 
metodikai kompetencia, szociális kompetencia, cselekvési kompetencia és kommunikációs kompetencia.

Hasonló felosztást, illetve fajtákat találunk az új OKJ kialakításánál, illetve a tartalmi és követelmény dokumentumok kidolgozásánál, amit az NSZI alkalmazott 20052006-ban.

Összefoglalóan elmondhatjuk: a kompetencia a posztindusztriális társadalom következményeként kialakult fogalom, melynek pedagógiai-pszichológiai lényege: operatív intelligencia, amely mindig cselekvésre vonatkozik (Bruner, 1974). Nem csak egyéni, hanem társadalmi jelentése is van.

\section{A BSc és MSc képzettségek elfogadása és karrier esélyei Németországban}

A német felsőoktatásban korántsem vezették be olyan egységesen és gyorsan az új, többciklusú felsőoktatási rendszert, mint Magyarországon. Számos diszkussziót, értékelő konferenciát szerveztek tartományonként és szövetségi szinten is. Végeztek közvélemény-kutatást is a különböző kvalifikációs szintek esélyeiről, a két szint közötti kompetencia különbségekről. Mindez arról (is) tanúskodik, hogy a tudományos igénnyel alátámasztott érvek és ellenérvek tisztító folyamatában jobban elö lehet készülni a megvalósításra.

Németország 1999-ben csatlakozott az ún. Bologna Nyilatkozathoz, és vállalta, hogy 2010-ig kialakítja az országban az oktatási rendszerét az Európai Felsőoktatási Térséghez igazodva. Különböző tanulmányok születtek a bachelor végzettségüek szakmába belépéseinek esélyeiről, a kvalifikációjuk értékeiről a korábbi diplomás végzettségüekkel szemben. Megjelentek az üzemek, a cégek ellenérzései, jelzései, amelyben szkepszisüknek adtak hangot. 2003-2004 között mintegy 672 üzemben töltötték ki a BSc és MSc karrierről és elfogadottságáról szóló kérdőívet. Négyes értéksálán kellett jelölniük a véleményüket (Értékskála: 1 - lényegtelen, 2 - inkább lényegtelen, 3 - inkább fontos). Ezekből a vizsgálatokból idézünk néhány adatot a témánk szempontjából releváns kompetenciákról (Konegen-Grenier, 2004).

2. táblázat: Szakirányú kompetenciák BSc. és MSc. jelölteknek

\begin{tabular}{|l|c|c|}
\hline \multicolumn{3}{|c|}{ Mennyire fontosak az alábbi szakirányú kompetenciák a BSc és az MSc jelölteknél? } \\
\hline & $M S c$ & $B S c$ \\
\hline Szakkompetenciák egy adott szakmára & 3,36 & 3,37 \\
\hline A szaktantárgy alapismeretei & 3,33 & 3,24 \\
\hline Szakkompetenciák egy tágabb szakmai körben & 3,29 & 3,16 \\
\hline A szakma konkrét ismerete & 3,06 & 2,97 \\
\hline Konkrét termékismeretek & 2,85 & 2,72 \\
\hline Különleges ismeretek az alkalmazott szakterületröl & 2,77 & 2,63 \\
\hline
\end{tabular}


3. táblázat: Szakmák feletti kompetenciák BSc. és MSc. jelölteknek

\begin{tabular}{|l|c|c|}
\hline \multicolumn{3}{|c|}{ Mennyire fontosak az alábbi szakirányú kompetenciák a BSc és az MSc jelölteknél? } \\
\hline & $M S c$ & $B S c$ \\
\hline Kommunikációs és team képességek & 3,72 & 3,67 \\
\hline Tanulási képesség & 3,70 & 3,66 \\
\hline Analizáló képesség & 3,70 & 3,43 \\
\hline Módszertani kompetencia & 3,55 & 3,26 \\
\hline Projekt menedzsment ismeretek & 3,43 & 3,19 \\
\hline Vezetői képességek & 3,39 & 3,06 \\
\hline
\end{tabular}

A fenti két táblázatból látható, hogy egyrészt a szakmai kompetenciák értékskála különbségei nagyobbak a BSc és MSc között, illetve 2-es értékskálájú körüli kategóriák is vannak, azaz ,inkább lényegtelenek”. Ugyanakkor a szakmák feletti (kulcs)képességek/kompetenciák egyike sem kerül a 3-as érték alá. Talán az sem meglepő, hogy a német üzemekben a müszakiak és egyéb diplomások esetében is a kommunikációs képességet tartják a legfontosabbnak.

\section{Fontosabb modellek a pedagógusképzésben és kompetencia fejlesztéseik}

\section{Az osztrák modell}

Itt most terjedelmi okokból csak egy képzőhelyet ismertetek, amely általában is lehet leképezője az Ausztriában folyó tanárképzésnek. A tudományegyetemeken szakmai tanárokat is képeznek. Valamennyi egyetemen okleveles (master szintü) tanárképzés valósul meg, amelyiknek a tartalmi és szervezési szerkezete, filozófiája nagyban hasonlít a németországiakéra.

A bécsi egyetemen (Universität Wien) külön karon, a Fakultät für Philosophie und Bildungswissenschaft három intézettel képezik az általános iskolai, a középiskolai közismereti és a szakmai tanárokat. A kar elnevezése is említésre méltó, hiszen azt szimbolizálja, hogy nem a „klasszikus neveléstudományi” teoretikus, hanem a praxisban előretörő át- és továbbképzéseket kidomborító képzési kurzusokra helyezik a hangsúlyt. Talán emlékeznek az olvasók, hogy a 70-es években Klagenfurtban megalakult International Gesellschaft für Ingenieurpädagogik (IGIP) bázishelyén, a klagenfurti egyetemen is volt egy rövid életü „Képzéstudományi Kar”.

Bécsben a szakképzési tanárok négyszemeszteres képzésének mai rendjét a kar, illetve az intézet konferenciája 2000 novemberében fogadta el, s amelynek lényege, hogy egybekapcsolja a pedagógiai tudományos szakmai előképzést és az iskolai gyakorlati képzést. 
A képzéssel kapcsolatos dokumentumokban rögzítik a fö célt, mely szerint a hallgatóknak el kell sajátítani a következő kompetenciákat: személyes, szociális, szakmai (pedagógiai, pszichológiai, didaktikai, képzésszociológiai, iskolaelméleti). Mindezeket a következő területeken kell hasznosítani: általánosan képező, szakmai, felső szakmai iskolákban, más képző intézetekben, a másod és harmad szakmai területek (gazdasági szektorok) képzései. Ebböl az derül ki, hogy a kompetencia területet pontosan körülhatárolják, illetve a szakképzés egészére kiszélesítették. Azt is érdemes megfigyelni, hogy a szakmai kompetenciákhoz sorolták a pedagógiai, pszichológiai, iskolaelméleti stb. területeket is.

A fenti kompetenciákhoz a következö készségeket és képességeket illesztették:

- tudományos gondolkodás és kutatás;

- módszertani vezetési képesség a tervek, cselekvések, az értékelés pedagógiai szituációiban;

- team munka képessége;

- visszajelzés a szaktudományos, szociális, pedagógiai-didaktikai és kommunikatív témákban;

- kritikai magyarázat a képzési rendszerről, a szakképzés struktúrájáról, a társadalompolitikai aspektusok megnyilvánulásairól;

- érzékeny észrevétele a társadalom és a környezet, a munka világa és a szakmák, valamint a tudomány és az etika kapcsolatának;

- érzékeny megértés az etnikai, a vallási és a kulturális sokféleség fejlődésének;

- kreatív válaszadás a sokféle eredetü konkrét kihívásokra.

Ebben az osztrák példában is kirajzolódik az a modell, hogy a képzési célban kompetencia tartalmi területeket, hasznositható területeket említenek, amihez képességeket rendelnek.

\section{Német modellek}

\section{A stuttgarti modell}

Az 1995-ös tanulmányutunkon is meggyőződhettünk a stuttgarti modell szerkezetéröl és „müködéséről” Antonius Lipsmayer elöadásaiban Karlsruheban, valamint a Stuttgarti Egyetem más előadóinak a bemutatásában. A további dokumentumok is arról tanúskodnak, hogy Németországban itt vezették be talán a legkorábban a szakmai tanárképzésben az ún. „kétfázisú” tanárképzést (Die zweite Phase der Ausbildung für Lehrer an beruflichen Schulen) (Scwab, 1995).

A képzés fázisai:

1. Főiskolai-egyetemi stúdiumok; Ezekben a főiskolai és/vagy egyetemi mérnöki tanulmányok mellett pedagógiai (szakképzés-pedagógiai) stúdiumokat is felvesznek, illetve egy másik modellben a müszaki(technikai) és a pedagógiai stúdiumok szerves egységet alkotnak. 
2. Referendariat (Sajátos tanári és hallgatói státuszú önálló, összefüggő tanítási gyakorlat).

Az ún. „ráépülő”, vagyis az okleveles mérnöki stúdiumok utáni képzés további jellemzői: két éves időtartamú és két szakterületen kell végezni. Vagyis az iskolai és az üzemi oktatás területén.

A képzés szervezete: a tanulás helye: szeminárium és a képző iskola. Képző iskola alatt azt a szakképző iskolát, (szakközépiskolát) értik, ahol a képzés közbeni iskolai/tanítási gyakorlatokat, valamint az államvizsga előtti egybefüggő gyakorló tanításokat végzik. A segítő (ellátó) személy: szakmai vezető/segítő tanár (mentor). A mentor feladata akkor az volt, hogy elsősorban a hallgatók oktatásmetodikai kompetenciáját fejlesszék, hogy segítse a jelöltet a tanóra megtartására való felkészülésében, majd a kiértékelésben irányt mutasson. Mivel az iskolai tanári közösségben zajló gyakorlat során a tanárokkal és a tanulókkal egyaránt interaktív és intenzív tevékenységet is végez a hallgató, ezért a mentor ebben a munkában is a segítö, irányító szerepet tölt be.

A modell meghatározó kompetenciái az oktatásmetodikai cselekvési kompetenciák, melyhez az alábbiak tartoznak:

- a tantervekből levezetett cselekvési célok

- célszerű tanítási stratégia kiválasztása

- tantervek az effektív oktatási cselekvésekhez

- objektív teljesítménybecslés/mérés

- innovációs képesség az új tantervi tartalmakhoz

Ezt a modellt nincs módunkban teljes egészében bemutatni, viszont egyértelmüen megállapítható, hogy tíz évvel a modell kidolgozása után a többciklusú képzésre való átállásnál is úttörő szerepet játszott a Stuttgarti Egyetem, mert már az 2004/2005-ös tanévben a BA és MA szintü szakmai tanárképzés rendszerére tértek át, máig meghagyva az előzőekben bemutatott és továbbfejlesztett képzési szerkezeteket és formákat.

A Bachelor Studiengang Pädagogik/Berufspädagogik 6 féléves és 180 „teljesítménypont”-os, vagy másképpen 180 kredites képzésben szerezhetnek tanári diplomát. Ez az egyik sajátosság, vagyis, hogy nem csak mester, hanem alapképzési szinten is lehet tanári oklevelet szerezni. A képzés szerkezetében meghatározó a modul és a kompetencia rendszer. Ebben a modellben a következö öt kompetencia fejlesztését határozzák meg a követelmények és a tantervek.

- $\quad \mathrm{A}=$ Analytische/orientierende Kompetenz (Analizáló, orientáló kompetencia)

- $\quad \mathrm{F}=$ Forschungsmethodische Kompetenz (Kutatás-módszertani kompetencia)

- $\mathrm{D}=$ Didaktische Kompetenz (Didaktikai kompetencia)

- $\mathrm{O}=$ Organisatorische Kompetenz (Szervezési kompetencia)

- $\mathrm{S}=$ Soziale Kompetenz (Szociális kompetencia) 
A 2008/2009-es tanévben a BSc szintű tanárképzésre épülő MA szintủ tanárképzést is meghirdették a mérnöki diplomával „kombinált” MSc tanárképzés mellett. Ez utóbbinak a neve: MSc Masterstudiengang Technikpädagogik. Ebben a Müszaki pedagógiai képzésben 9 félév alatt lehet eljutni az „első” államvizsgáig, ahol Okleveles Ipari (Müszaki) tanári címet lehet szerezni, amit egy 19 hónapos, konkrét iskolában megvalósított „Szemináriummal” kiegészítve tehetik le a második államvizsgát. Mellőzve ennek a bonyolultnak tünő képzésnek a szerkezeti-tartalmi szabályozási kérdéseit a kompetenciákkal kapcsolatban érdemes még kiemelni, hogy az egyes előadások, szemináriumok, kompaktszemináriumok leírásában minden tantárgynál megadják a fejlesztendő kompetenciák betüjelét.

Az általános pedagógiai tantárgyak előadásai közül a Bevezetés a Pedagógiábal Iskolapedagógiába, illetve Bevezetés a Pszichológiába c. tantárgyak között kell választani. További tartalmi területi választási lehetőség is van az alábbi négy közül.

- Az iskola mint intézmény

- Az iskola szocio-kulturális környezete

- Tanári kompetenciák

- Tanulási és tanítási eljárások, módszerek

Stuttgartban a szakmai tanárképzés valamennyi modelljében nagy hangsúlyt fektetnek az iskolai és az üzemi gyakorlatra, valamint az ezekkel összefüggő kompetenciák fejlesztésére. A müszaki pedagógia szakon diplomát szerzők szakképző iskolákban, szakmai továbbképző helyeken, tananyag fejlesztési területen és a tudományos munkát végzö helyeken tudnak elhelyezkedni.

\section{Alsószász modell}

A tartományi különbségek néha nehezen fogalmazhatóak meg, de itt jól kirajzolódik a képzési szerkezethez kötődő ,gyakorlatias kompetenciák” dominanciája. Ez a modell filozófiájában hasonlít a mi mostani tanárképzési MSc modellünkhöz, mert a „pedagógiai karakter" egy sajátos kompetenciát is igényel(ne), ami Niedersachsenben a Vermittlungskompetenzen-t (közvetítési kompetencia) jelenti (Kultusministerkonferenz - KMK, 1999).

A 2. ábra a Németországban, Alsószász (Niedersachsen) tartományban bevezetett BSc. és MSc. képzések menetének alapszerkezetét vázolja fel.

Általában elmondható ezen évfolyamok tartalmi szempontjairól, hogy már nem az egyes tantárgyak egyetemi szintü tényelvüségére és tudományos módszertanára helyezik a hangsúlyt, hanem a valós iskolai terepre, élethelyzetekre koncentrálnak, azaz azokra a kompetenciákra, melyekre a leendő tanároknak a mindenkori iskolaszinteken és iskolaformákban szükségük lesz. Az oktatás irányultsága már nem a tudományágak saját módszertanán alapul, hanem a különböző szaktantárgyak szabják meg. 
A BSc (bachelor) képzés alapszerkezete Alsószász képzési modell

Szakdolgozat készítése 6-15 kredit

Főszak (major fölérendelt)

(1. szak vagy szakmai szakirány)

kb. 80-100 kredit

\section{vagy}

1. szak (mellérendelt) kb. 54-67,5 kredit
Mellékszak (minor alárendelt)

(2. szak)

kb. 30-50 kredit
Szakmai gyakorlat megszerzése

kb. $20-50$ kredit.

A pontok

2-3 szakmai

gyakorlatot tartalmaznak

(részben

a szakágban)

Szabvány tanulmányi idők

Alsószász képzési modell

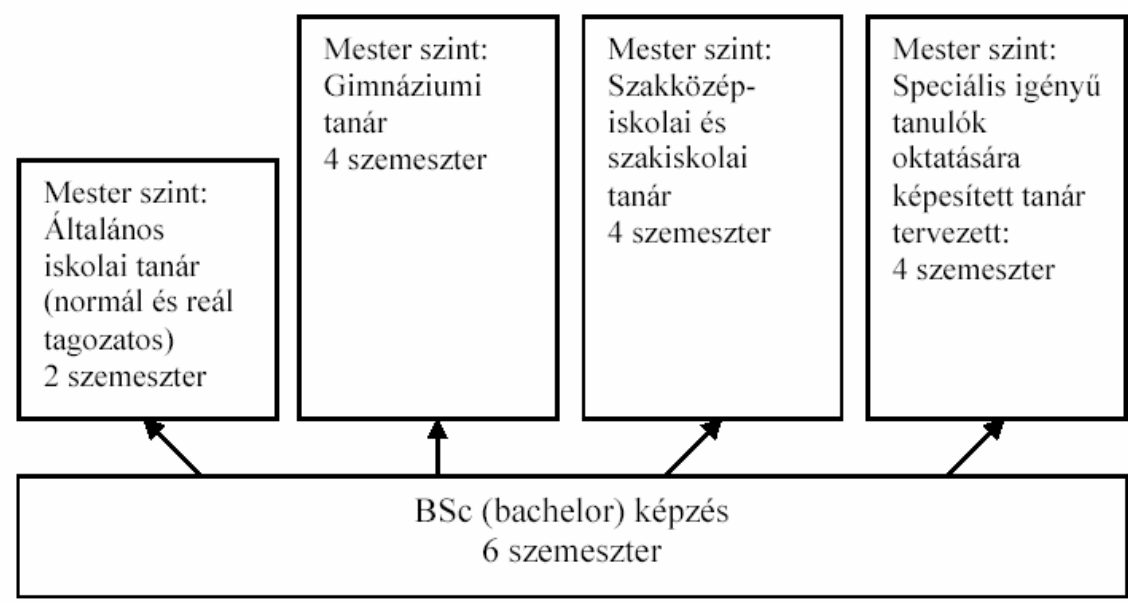

2. ábra: Alsószász felsőoktatási modell 
Ebben az összefüggésben a tanárképzés BSc és MSc szerkezeteit összefogó tervben (,Verbundhaben Bachelor/Master-Strukturen in der Lehramtausbildung”) megfogalmazott koncepcióban az alsószász föiskolák közösen négy pontot fogalmaztak meg, különös tekintettel az alábbiakra:

- A különböző szakos tanárhallgatók két szaktantárgyban szerezhetnek tudományos ismereteket: ezzel a szakjaik mindenkori tudományos helyzetét ismerik meg, valamint aktuális tudományos módszertant és tudásgyarapítási készségeket sajátíthatnak el.

- Az első szemeszterben megismerkednek azokkal a neveléstudományi és pedagógiai-pszichológiai alapokkal, amelyek a közvetítési kompetenciához szükségesek

- A tanári kommunikáció képességeinek fejlesztése nem csak elméleti megalapozást nyer, hanem tréningeken is fejlesztik. A gyakorló iskolai tanítás során alkalmazzák is és továbbfejlesztik.

- Az információs technológiák a tanári munkában fontosak, ezért az informatikai kompetenciák fejlesztése az oktatás technológia alkalmazásához kötődően kerül megoldásra.

Hamburgi modell

Aki a hamburgi egyetemen beiratkozik valamilyen szaktanári képzésre, tanulmányai során egészen más dolgokat fog elsajátítani, mint amelyekre más német tartományban lehetősége lenne. Itt ugyanis szaktantárgyai mellett a neveléstudományt is önálló tantárgyként tanulja. Ezért ebben a tantervben a „,neveléstani részkurzus”ról esik szó. Az óraszám ebben a kurzusban összesen kb. 40 óra/hét egy szemeszterben. A kurzus két részből áll: a szükebb értelemben vett neveléstudományból és az oktatott tantárgy didaktikájából (szakdidaktika).

A szükebb értelemben vett neveléstudomány foglalkozik a neveléssel, a képzés és a szocializáció összefüggésével, az iskolai és iskolán kívüli tanítás és tanulás kérdésével. A szakdidaktikák a hallgatott szaktantárgyat neveléstudományi résztudományként kezelik: tárgyukat képezik a szakspecifikus célok, tartalmak, módszerek és az oktatási média. A tanítás-tanulás folyamatának elemzése és alakítása során tekintettel vannak szakági és neveléstudományi ismeretekre.

A kurzus eredményes lezárásához tudni kell, hogy a neveléstudomány tantárgy érdemjegye az első államvizsgánál ugyanolyan arányban számít, mint más tantárgyak érdemjegyei, és az otthon elkészített szemináriumi beszámolókat is bevonják az összesítő értékelésbe.

Megjegyzendő, hogy az összevont alap- és középfokú oktatásban való részvételre képzett szaktanár-hallgatók a neveléstudománnyal egy időben „Általános iskolai pedagógiát" is tanulnak. 
A felsőfokú képzés célja a megfelelő tanulmányi és vizsgarend kialakítása, ami előkészít a Referendariátra (sajátos hallgatói-tanárjelölti státusz az önálló iskolai gyakorlat során), és mely által a hallgatók a jövendő oktatói tevékenységük során megfelelően alkalmazható neveléstudományi képességeket és ismereteket sajátítanak el. Ebben az értelemben a „neveléstani részkurzus” azt célozza meg, hogy a hallgatókat felkészitse a pedagógia különbözö területein való, tudományosan megalapozott cselekvőképességre. A későbbi szakmai tevékenységgel szemben a képzés cselekvéskényszertől mentesen esélyt ad a professzionális cselekvési képesség kipróbálására éppúgy, mint a különböző élethelyzetekre, veszélyekre és problémákra való elméleti válaszadásra. Itt abból indultak ki, hogy a tudományos képzés és a cselekvőképesség kialakítása között rémisztő, de alkalomadtán inspiráló kapcsolat van.

A képzés céljai részletesen:

- Neveléstudományi szakkompetencia kialakítása: ezen belül a neveléshez kapcsolódó ismeretek és képességek elsajátítása, valamint meghatározott teoretikus kontextusokban adódó problémákra való válaszadás képességének kialakítása.

- Metodikai kompetencia kialakítása: azaz problémák és feladatok megfelelő, elméletileg alátámasztott megoldása.

- Szociális kompetenciák kialakítása: azaz szociális kapcsolatok és vonatkozások helyes értelmezése, a feladatok csapatmunkában való megoldása.

- Személyes kompetenciák kialakítása: azaz a különböző szociális helyzeteket képes legyen saját személyes tapasztalatai figyelembevételével megtervezni, ezt tudatosan tegye, és szilárd realitásérzéke legyen.

Sajátos felfogást, illetve a gyakorlatban megvalósuló és egyben nehézséget okozó rendszer a mentor rendszer. Ennek alapja az, hogy a szakterület struktúráinak és a tanítás tanításának megismerésére a legjobb lehetőségnek tartják a szoros, hivatalos oktatási alkalmakon túllépő kapcsolatot tanár és tanítvány között. Szakmai körökben ezért kifejlesztettek egy ún. mentorprogramot, amely lehetővé teszi a hallgató számára, hogy a második szemeszter felvételekor egy tanárt mentorává választhasson, akivel rendszeresen megbeszéli tanulmányi programját. Habár sok tanár részt vesz a programban, számuk egyelőre mégsem elegendő ahhoz, hogy az összes hallgató részéről jelentkező igényt egy helyen és egy mentorcsoporttal kielégítse. A mentorválasztás eredményes lehet a gyakorlatba történő bevezetésben, de többek között megalapozhatja például a szakdidaktikai proszemináriumokat is. Ugyancsak fontos, és irányt mutató lehet számunkra az alábbi két iskolán kívüli gyakorlat, amelyekröl rövid ismertetőt adok a következőkben.

Az Iskolán kívüli gyakorlat, például a Szociális gyakorlat (ISoP) lehetőséget biztosít a hallgatóknak arra, hogy tapasztalatokat gyüjtsenek az iskolán kívüli pedagógiai területekről, és olyan nevelési kompetenciát alakítsanak ki, amelynek hasznát veszik majd az oktatásban. Gyakorlati helyként szóba jöhetnek olyan szo- 
ciálpedagógiai létesítmények, mint pl. napközi otthonok, nyári táborok, ifjúsági házak, felügyelt játszóhelyek stb. De az utóbbi évtizedben az iskolákban is megjelentek különböző szociálpedagógiai feladatok, mint például osztálykörök, tanácsadások, iskolai szociális munka és játékpedagógiai lehetőségek. A hallgatók ezeken a helyeken is tudják teljesíteni az iskolán kívüli gyakorlatot. Tehát a „szociálpraktikumot" nem feltétlenül az iskola keretein kívül kell teljesíteni, hanem az órarendi oktatáson kívül.

Az integrált üzemi gyakorlat (IBP) a kísérőszemináriummal együtt olyan feladatok elé állítja a hallgatót, amely összefüggésben áll az általános ismereteket adó iskolák tanulóinak szakmai orientációjával és szakmaválasztásának előkészítésével. Ez a négyhetes gyakorlat teljes egészében üzemi létesítményben zajlik. Előzmény és megszilárdítás egyben a két szemeszterre osztott szeminárium, összesen heti két órában. Elvárják egy gyakorlati napló készítését az eredményes részvétel igazolásaként. A tapasztalatok szerint többnyire olyan hallgatók választják az üzemi gyakorlatot, akik már rendelkeznek valamilyen képesítéssel, és a választott szakterület kapcsolódik a korábbi szakmai tevékenységükhöz.

\section{Az IGIP modell}

Az 1972-ben Klagenfurtban megalakított Nemzetközi Mérnökpedagógiai Társaság kezdettől fogva foglalkozott a szakmai (mérnök)tanárok képzésének, továbbképzésének tartalmi, szervezeti kérdéseivel. Az évenkénti konferenciák, szimpóziumok mindig helyt adtak a müszaki tanárképzés témáinak, az utóbbi 10 évben önálló szekció keretében.(Technical Teacher Training). Az IGIP számos közép-kelet európai országban kiépítette tagsági hálózatát, megismerte az adott ország mérnök- és mérnök-tanárképzési rendszerét. Ez indította el a társaság vezetését abba az irányba, hogy a müszaki terület tanárképzésének tantervét szisztematikusan fejlessze. Az IGIP Mérnökpedagógiai Tanterv fejlesztésében kezdettől fogva nagy szerepet vállalt a társaság első elnöke, Adolf Melezinek.

Az ING-PAED IGIP-Curriculum megújításánál egy stabil alapból tudtak kiindulni: az eddigi, Adolf Melezinek által kifejlesztett tanterv lényegében egy személyes gondolatmenetet leírő curriculum volt, amelyre 1993 óta számos föiskolán sok országban, mint egy technikusoknak, mérnököknek szóló továbbképzési programként tekintettek.

Azóta a tantervről szóló mérnökpedagógiai és szaktudományos vita álláspontját, és ennek megújítását - különösképpen az IGIP - munkacsoportban (Technical Teacher Tarining) folyó tevékenység vezetett oda, hogy az évenként megismétlődő IGIP-szimpózium a fejlesztéseket nyilvánossá tette. Ebben a fejlesztő munkában létrehoztak egy szük munkacsoportot (Technical Teacher Training) Adolf Melezinek vezetésével, amelyben az operatív munkák koordinálását Bernd Lübben (Uni Hannover) és Vera Ziroff végezték. Ebbe a munkába a nemzetközi team tagjaként 
részfeladatot végeztem. A fejlesztés egyik alternatívája: Jövőorientált „ING-PEAD IGIP-Tanterv" elnevezésü modell lett, amelynek eszménye az, hogy a mérnöki tanulmányokkal párhuzamosan folyó mérnökpedagógiai stúdiumok megőrizzék a müszaki és a pedagógiai gondolkodás és praxis értékeit, összekapcsolják a szakmai és pedagógiai tudományos ismereteket a korszerü IKT alapú módszerekkel, és etikai dimenziókkal hassák át a jelöltek felkészítését.

\section{Mérnökpedagógiai kompetenciák}

Az IGIP-vezetősége jóváhagyta a nemzetközi monitoring bizottság 2005. szeptember 11-én hozott határozatát, amely kijelölte a mérnökpedagógusi kompetenciák körét (IGIP Report N0 34, 2006). Ezek az általános kompetenciák két nagy csoportból állnak: technikai, müszaki szakkompetenciákból és tipikus mérnökpedagógiai kompetenciákból.

Mérnökpedagógiai kompetenciákat összefoglalva:

- Pedagógiai, szociális, pszichológiai és normatív-etikai kompetenciák,

- Szakdidaktikai kompetenciák,

- Értékelési kompetenciák,

- Szervezési (menedzsment) kompetenciák,

- Önfejlődési kompetenciák,

- Kommunikatív és kollegiális kompetenciák.

1. Technikai (müszaki) kompetenciák: feltételezett egy magas technikai szakkompetencia, ami jelenti egy elismert és/vagy akkreditált mérnöki felsőfokú tanulmányok és ezekhez csatlakozó szakmai tapasztalatok megszerzését (lásd 3.2 pont alatt: az IGIP mérnökpedagógiai képzésre vonatkozó akkreditálási kritériumait).

2. Pedagógiai, szociális, pszichológiai és normativ-etikai kompetenciák. A mérnöktanár:

2.1 jó munka- és tanulási légkört teremt;

2.2 a tanulókat partnernek tekinti és kölcsönös tiszteletet kialakításán dolgozik;

2.3 csoportdinamikai folyamatokat kezel, interakciókat ösztönöz, stimulál a tanár és tanuló, valamint a tanuló-tanuló között;

2.4 hasznosítja a tanulók teljesítményét, és teret ad a kreativitásnak;

2.5 támogatja a tanulókat a (szakmai) identitásuk fejlődésében;

2.6 ösztönzi az értékorientációt (Value Orientation);

2.7 szakmacsoportjának reprezentatívjaként (mintájaként) viselkedik.

3. Szakdidaktikai kompetenciák. A mérnöktanár:

3.1 a tanítás folyamán alkalmazza a mérnökpedagógiai modelleket a tanításának előkészítésben és megvalósításában; 
3.2 tanításában felhasználja az információs csatornák változatai;

3.3 tanítása folyamán figyel a hatdimenziós oktatási tér kompetenciájára, és beépíti a választott tanulási módszerébe;

3.4 bepillantást nyújt a választott didaktikai módszerbe és egyeztet a kollégákkal és a diákokkal erről;

3.5 egyértelmủ tanítási célokat, tananyagválasztást és tananyagstruktúrát használ a tanításban;

3.6 választ, az ismert tanítási folyamatok összetevőit figyelembe véve, az optimális módszerek és stratégiák közül, például: labordidaktika és projekt módszer;

3.7 fontosnak tartja a szemléletességet és a megérthetőséget, és ennek megfelelően cselekszik;

3.8 integrálja az új fejlesztéseket technikailag és didaktikailag a saját tanításában;

3.9 inspiráló tankörnyezetet teremt a tanulóknak;

3.10 használja az úgynevezett klasszikus oktatási médiákat, valamint a kifejezett információhordozók optimális beállitását és megfelelően használja az új ICT-médiákat (pl.: tan-plattformokat, Notebook-osztályokat stb.);

3.11 figyel a tanulási folyamatban résztvevő tanulók közötti különbségekre (pl.: kultúrák közötti különbségek);

3.12 alkalmazza a tanulók tapasztalatait, és ösztönzi a tanulókat, hogy ezeket a tapasztalatokat ültessék át a gyakorlatba a személyes (szubjektív) munkamódszerükbe. Használják a portfoliójuknál;

3.13 ösztönözze a diákokat:

- tapasztalataikon való elmélkedésre (reflektálásra),

- saját tanulási folyamatuk feletti felelősségükre,

- saját maguk professzionális, hivatásos mérnökként való megítélésére.

4. Értékelési kompetenciák. A mérnöktanár:

4.1 eszközöket (mérőeszközöket) fejleszt ki a mérnöki kompetenciák megítéléséhez;

4.2 a tanulókat többek között megítéli, értékeli;

4.3 felügyeli a tanulók tanmenetben lévő előírásait, és jegyzi azokat.

5. Szervezési (menedzsment) kompetenciák. A mérnöktanár:

5.1 kiváló fizikális és virtuális tanulási környezetet teremt;

5.2 jól szervezi a munkáját és az idejét;

5.3 figyel a fontos igazságokra, és nyomon követi a képzéspolitikát;

5.4 adminisztrálja a fontos, megfelelő adatokat;

5.5 improvizál, ha kell. 
6. Kommunikativ és kollegiális kompetenciák. A mérnöktanár:

6.1 több szakterületet érintö teamekben dolgozik;

6.2 megmagyarázza a saját oktatási koncepcióját, összhangba hozza a kollégáiéval és beszélgetnek ezekröl;

6.3 a koncepciók fejlesztésében képviseli a saját szervezését és a tanítás megújítását;

6.4 fontos regionális és nemzetközi munkahálózattal, kapcsolatokkal rendelkezik;

6.5 fontosnak tartja a mérnökpedagógiai felfedezéseket/újításokat és kommunikál/beszélget ezekről;

6.6 szóban és írásban közöl különböző fontos összefüggésekben;

6.7 tudományos írásokat ismer.

7. Önfejlesztési kompetenciák. A mérnöktanár:

7.1 megbecsüli az új fejlesztéseket (pl.: új technológiákat) és beépíti az egyéni oktatásba;

7.2 rendszeresen reflektál az egyéni módszeréről/didaktikájáról, és az egyéni tanulási viszonyáról;

7.3 láthatóan alakítja a kollégái és diákjai előtt a tanmenetet;

7.4 mérnöktanárként felkészült és alkalmas egy IGIP-akkreditálás és egy IGIP-regisztrálás előkészítésére.

Az IGIP-kerettanterv struktúrája, szakterületei és moduljai

A Modul-kézikönyvben előállított séma adja a struktúrát és a modulok összefonódását, továbbá a mérnökpedagógiai kerettanterv egyes moduljainak és szakterületeinek (ECTS) kreditpontját. A magmodul a Mérnökpedagógia elméletben és gyakorlatban, valamint ennek folytatása, a Labordidaktika bázis-modul képezik a tanterv alapját. A pszichológiai és szociológiai aspektusok modul a pszichológia és szociológia klasszikus szakterületei, és olyan biológiai tartalommal választható, amelyek a mérnöktanároknak a tanításnál és a gyakorlatban szükségesek. Ez a modul a kerettanterv összes moduljának alapjaként szolgál. A Média, e-Learning, számítógéppel támogatott technológiák bevezetnek a modern médiák ésszerü felhasználásába. A mai mérnökképzésben és gyakorlatban egy új kifejlesztett modul a projektmunka. Nemzetköziségét és mobilitását tekintve a tanulók és a dolgozók jelentős etikai kérdéseket vetnek fel szakmai oldalról, ezért a mérnökök az interkulturális kompetenciákat és az etikai aspektusok modult is felveszik. A modulleírások mind nyitottak, hogy a képzésben részt vevő államok, régiók különbségei meg tudjanak jelenni a követelményekben, és azokat a hely adottságainak megfelelően pontosítani tudják. 
Portfolió és záróvizsga

Az IGIP - Akkreditálási kritériumok 3.4-es fejezetében leírtakkal összhangban, a mérnökpedagógus rendszerben résztvevők a tanulmányaik alatt munkájukat, eredményeiket egy portfolióban dokumentálják. Ez a tanárjelölt bizonyítványa, amely az egyén modulok szerinti elörehaladását is tartalmazza.

A záróvizsgák letételéhez, a mérnökpedagógiai kollokviumra, az egész tantervet el kell végezni, és elemezni kell egy tanulásszervezésről szóló videofelvételét. Ez a didaktikai esettanulmány mutatja meg a jelölt felkészültségét, és mindezt a portfolióban dokumentálja is.

A képzés modulszerkezete (Egy konkrét modul bemutatását lásd a Mellékletben)

\begin{tabular}{|l|l|c|}
\hline \multicolumn{2}{|l|}{ Modulmegjelölés } & $K P$ \\
\hline PM1 & Mérnökpedagógia elméletben és gyakorlatban & 6 \\
\hline PM2 & Labordidaktika & 3 \\
\hline PM3 & Pszichológiai és szociológiai aspektusok & 3 \\
\hline PM4a & Retorika, kommunikáció & 2 \\
\hline PM4b & Értelemszerü tesztkonfigurációk, tudományos dolgozat & 1 \\
\hline PM5 & Projektmunka & 2 \\
\hline PM6 & Média (közvetítés-oktatástechnológia) & 2 \\
\hline & $\begin{array}{c}\text { Választási lehetőség: } \\
\text { WPM } \quad \text { WPM1 - Etikai aspektus }\end{array}$ & 1 \\
\hline & $\quad$ WPM2 - Interkultúrális kompetenciák & \\
\hline
\end{tabular}

\section{Irodalom}

Bruner, J. S. (1974): Új utak az oktatás elméletéhez. Gondolat Kiadó, Budapest.

IGIP-Regionaltagung Nordeuropa an der Technischen Universität Hamburg, Harburg: Die Bedeutung der Ingenierpädagogik Wo stehen wir, Wohin wollen/müssen wir? 3-5. März 2006.

IGIP Report N0 34 (2006): IGIP Akkreditationskriterien für die Ingenieurpädagogische Ausbildung und Ingenieurpädagogische Kompetenzen. Moscow, 35-44., 45-73.

International Forschungsseminar (2004): Studienplan Erziehungswissenschaft für das Lehramt an der Grund- und Mittelstufe und für das Lehramt der Oberstufe. UNI Hamburg.

Konegen-Grenier, C. (2004): Akzeptanz und Karrierschancen von Bachelor- und Masterabsolventen deutscher Hochschulen W-Etrends, 3. sz. 1-17.

Kultusministerkonferenz (KMK) (1999): Strukturvorgaben für Einführung von Bachelor/Bachalaureus- und Master/Magisterstudiengängen, Beschluss der KMK v. 05.03. 1999, Bonn. 
Nölker, H., Spreth, G. (2001): ENTWURF Von MES zu MEQ-Revision des Modularen Ausbildungskonzepts der Internationalen Arbeitsorganisation (ILO)

Scwab, G. (1995): Die zweite Phase der Ausbildung für Lehrer an beruflichen Schulen Stuttgart, FH(TU)

Spreth, G., Stollte, H. (2003): Foglalkozás orientált szakképzési modell (MTP=Modular Training Package) InWent Berlin.

Stollte, H. (2000): Modularisierung in der beruflichen Aus-und Weiterbildung Erfarungen im nationalen, und internationalen Kontext. ZGB Mannheim, Magdeburg

Szervezetfejlesztők Magyarországi Társasága (1999): A kompetencia fogalma. Budapest.

Tóth Béláné (2006): A szakmai pedagógusképzés nemzetközi összehasonlitó elemzése. NSZI Budapest.

www.institut.erz.univie.ac.at

http//www.uni-hamburg.de

\section{MELLÉKLET}

\section{Egy konkrét modul bemutatása}

Kötelező modul 2 - Labormódszertan (Labordidaktika)

\begin{tabular}{|c|c|}
\hline & Magyarázat/Leírás \\
\hline Név & Labormódszertan \\
\hline Kreditpontok & 3 \\
\hline Jelenléti idő & 36 óra \\
\hline $\begin{array}{l}\text { Tanulási célok } \\
\text { Kompetenciák }\end{array}$ & $\begin{array}{l}\text { A labormódszertani modul különösen megerösíti a hallgatók } \\
\text { szociális, szervezési, kommunikációs, etikai kompetenciáit és } \\
\text { alkalmassá teszi őket, hogy: } \\
\text { - } \quad \text { a módszertanilag felépített laborórák megírására; } \\
\text { - } \quad \text { egy módszertanilag felépített mediális betét, beleértve } \\
\text { az elektronikus médiát, megtervezésére; } \\
\text { - } \quad \text { a hallgatókat, mint partnert kezelni - az emberek közötti } \\
\text { kapcsolatok jelentőségének tudatában magában a tanulásban } \\
\text { és a különféle kulturális jellegzetességekben; } \\
\text { - a technikával való összefüggés különleges jelentőségére, } \\
\text { a felelösség vállalására és ennek továbbadására: tekintettel } \\
\text { a labor biztonsági kérdéseire csakúgy, mint a humán, szociális, } \\
\text { ökológiai következménybecslésre a technikai produktumokra } \\
\text { való tekintettel. }\end{array}$ \\
\hline
\end{tabular}




\begin{tabular}{|c|c|}
\hline & Magyarázat/Leirás \\
\hline Elöfeltételek: & 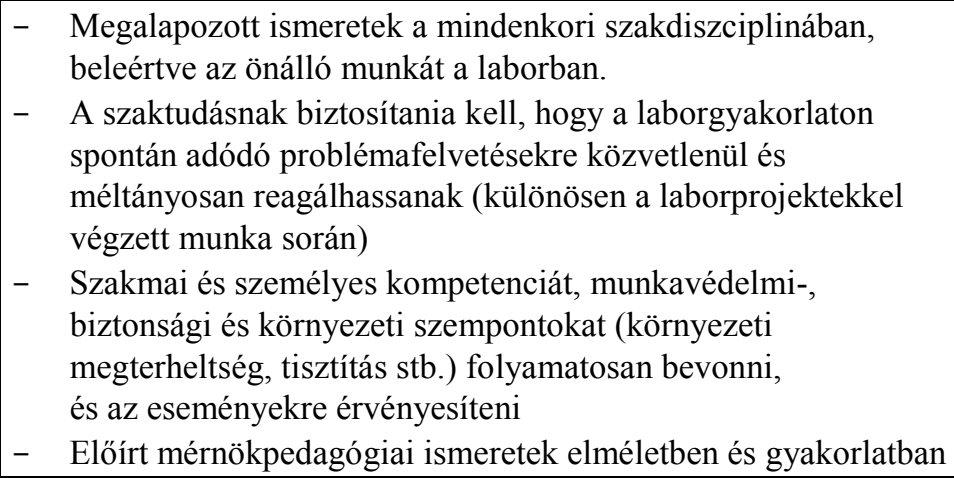 \\
\hline Kimenti szint & Az IGIP-akkreditációs kritériumoknak megfelelő \\
\hline $\begin{array}{l}\text { Ajánlott tanítási } \\
\text { forma }\end{array}$ & $\begin{array}{l}\text { Szeminárium beleépített gyakorlattal (a mérnökpedagógiai } \\
\text { gyakorlat folytatása) }\end{array}$ \\
\hline Státusz & Kötelezö modul \\
\hline Ajánlott vizsgaforma & $\begin{array}{l}\text { Lsd. az IGIP akkreditációs kritériumok 3.4-es pontját } \\
\text { A portfólió tartalmazza: Egy laborgyakorlat koncepcióját } \\
\text { 1) tekintettel az összes szemeszterre } \\
\text { 2) egy gyakorlati nap részletes megtervezését, figyelembe véve } \\
\text { a labormunkák összes aspektusát (lsd. tartalmak), } \\
\text { 3) és az ahhoz tartozó kidolgozott laboróra dokumentációját. }\end{array}$ \\
\hline A modul befejezése & Rendszeres aktív részvételnél \\
\hline Elismert modulok & Hasonló tartalmú modulok \\
\hline
\end{tabular}




\begin{tabular}{|c|c|}
\hline & Magyarázat/Leirás \\
\hline Tartalom & $\begin{array}{l}\text { 1) A különböző szintek és metódusok a labormunkában: } \\
\text { az integrált labortól a projektorientált laborig és } \\
\text { a diplomamunkáig } \\
\text { 2) A megértéstől az irányított kísérletezéseken át az egyedüli } \\
\text { kísérletezésekig: a tanulás elöre haladó komplexitása, értekezés } \\
\text { és megértés a labormunka különböző fokozatain, } \\
\text { 3) A labormunka ismeretelméleti és empirikus aspektusai: } \\
\text { a technikai rendszerekkel való megismerkedés és/vagy } \\
\text { életszerüség adják a labor történelmi és kulturális jelentőségét. } \\
\text { 4) A szociális kompetencia megerósítése a laborban: a retorika és } \\
\text { prezentáció, kommunikáció és team-munka elemeinek } \\
\text { átgondolt alkalmazása. } \\
\text { 5) Az elektronikus média alátámasztott bevetése/alkalmazása } \\
\text { a laborgyakorlatokon és a laborgyakorlatok elökészítésénél. } \\
\text { 6) Aspektusok a laborutasítások és jegyzetek kialakításához, } \\
\text { a labormunka különböző fokainak megfelelően. } \\
\text { 7) A laborbeszámolót a különböző fokú labormunkáknál milyen } \\
\text { átgondolt módon (szóban és/vagy írásban) várják el? } \\
\text { 8) A labormunka interkulturális aspektusa, pl. a nyelvi korlátok } \\
\text { kihatásai, különböző viszonyulások a mindennapi } \\
\text { szituációkban, a labormunka során. }\end{array}$ \\
\hline Ajánlott irodalom & Pl.: ... \\
\hline További tanácsok & $\begin{array}{l}\text { A tanácsokat Albert Haugé adja, aki az IGIP labormódszertani és } \\
\text { a projektek munkával kapcsolatos szimpóziumainak keretében egy } \\
\text { átfogó képet a modul elméletébe. } \\
\text { A labordidaktikai modul a mérnökpedagógia (elmélet és gyakorlat) } \\
\text { tartalmával való intenzív foglalkozást feltételezi. A labordidaktikai } \\
\text { gyakorlatok csak előrehaladott mérnökpedagógiai gyakorlati } \\
\text { ismeretekkel mehetnek végbe. } \\
\text { A vizsga labordidaktikából csak a sikeresen letett } \\
\text { mérnökpedagógiai profilt követheti. }\end{array}$ \\
\hline
\end{tabular}

